\title{
A kórelőzményben szereplő revascularisatiós mǘtét rövid és hosszú távú prognosztikai jelentősége szívinfarktus miatt kezelt betegekben
}

\author{
Jánosi András dr. ${ }^{1}$ - Ferenci Tamás dr. ${ }^{2,3}$ \\ Komócsi András dr. ${ }^{4}$. Andréka Péter dr. ${ }^{1}$ \\ ${ }^{1}$ Gottsegen György Országos Kardiovaszkuláris Intézet, Nemzeti Szívinfarktus Regiszter, Budapest \\ ${ }^{2}$ Óbudai Egyetem, Élettani Szabályozások Kutatóközpont, Budapest \\ ${ }^{3}$ Budapesti Corvinus Egyetem, Statisztikai Tanszék, Budapest \\ ${ }^{4}$ Pécsi Tudományegyetem, Általános Orvostudományi Kar, Szívgyógyászati Klinika, Pécs
}

Bevezetés: A szívinfarktust megelőző revascularisatiós beavatkozások prognosztikai jelentőségével kapcsolatban kevés elemzés ismeretes, hazai adatokat eddig nem közöltek.

Célkitüzés: A szerzők a Nemzeti Szívinfarktus Regiszter adatait felhasználva elemezték a koszorúér-revascularisatiós szívmútétet $(\mathrm{CABG})$ túlélt betegek prognózisát heveny szívinfarktusban.

Módszer: Az adatbázisban 2014. 01. 01. és 2017. 12. 31. között 55599 beteg klinikai és kezelési adatait rögzítették: 23437 betegnél $(42,2 \%)$ ST-elevációval járó infarktus (STEMI), 32162 betegnél (57,8\%) ST-elevációval nem járó infarktus (NSTEMI) miatt került sor a kórházi kezelésre. Vizsgáltuk a CABG után fellépó infarktus miatt kezelt betegek klinikai adatait és prognózisát, amelyeket azon betegek adataival hasonlítottunk össze, akiknél nem szerepelt szívműtét a kórelőzményben (kontrollcsoport).

Eredmények: A betegek többsége mindkét infarktustípusban férfi volt (62\%, illetve $59 \%)$. Az indexinfarktust megelőzően a betegek 5,33\%-ánál $(\mathrm{n}=2965)$ történt CABG, amely az NSTEMI-betegeknél volt gyakoribb $(\mathrm{n}=2357$; 7,3\%). A CABG-csoportba tartozó betegek idősebbek voltak, esetükben több társbetegséget (magas vérnyomás, diabetes mellitus, perifériás érbetegség) rögzítettek. Az indexinfarktus esetén a katéteres koszorúér-intervenció a kontrollcsoport STEMI-betegeiben gyakoribb volt a CABG-csoporthoz viszonyítva (84\% vs. 71\%). Az utánkövetés 12 hónapja során a betegek 4,7-12,2\%-ában újabb infarktus, 13,7-17,3\%-ában újabb katéteres koszorúér-intervenció történt. Az utánkövetés alatt a CABG-csoportban magasabbnak találtuk a halálozást. A halálozást befolyásoló tényezők hatásának korrigálására Cox-féle regressziós analízist, illetve 'propensity score matching' módszert alkalmaztunk. Mindkét módszerrel történt elemzés azt mutatta, hogy a kórelőzményben szereplő koszorúér-revascularisatiós mütét nem befolyásolta a túlélést. Amennyiben a beteg kórelőzményében szerepelt a koszorúérmútét, az indexinfarktus nagyobb eséllyel volt NSTEMI, mint STEMI (HR: 1,612; CI 1,464-1,774; p<0,001).

Következtetés: A kórelőzményben szereplő koszorúér-revascularisatiós mútét nem befolyásolta a szívinfarktus miatt kezelt betegek életkilátásait.

Orv Hetil. 2021; 162(5): 177-184

Kulcsszavak: szívinfarktus, koszorúér-revascularisatiós mútét, prognózis, szívinfarktus-regiszter

\section{Short- and long-term prognostic significance of previous recanalization interventions in patients treated for myocardial infarction}

Introduction: Little analysis is known about the prognostic significance of revascularization interventions before myocardial infarction; no domestic data have been reported so far.

Method: The authors use data from the Hungarian Myocardial Infarction Registry to analyze the prognosis of patients with acute myocardial infarction who had previous coronary artery bypass grafting (CABG). Between 01. 01. 2014. and 31. 12. 2017, 55599 patients were recorded in the Registry: 23437 patients (42.2\%) had ST-elevation infarction (STEMI) and 31162 patients (57.8\%) had non-ST-elevation infarction (NSTEMI). The clinical data and prognosis of patients treated for infarction after CABG were compared with those of patients without a CABG history. 
Results: The majority of patients were male (59\% and $60 \%$, respectively). Prior to index infarction, CABG occurred in $5.33 \%$ of patients $(\mathrm{n}=2965)$, which was more common in NSTEMI $(\mathrm{n}=2357 ; 7.3 \%)$. The CABG patients were older and had more comorbidities (hypertension, diabetes mellitus, peripheral vascular disease). For index infarction, percutaneous coronary intervention was more common in STEMI patients in the control group compared to CABG ( $84 \%$ vs. $71 \%)$. At 12 months of follow-up, $4.7-12.2 \%$ of patients had reinfarction, and $13.7-17.3 \%$ had another percutaneous coronary intervention. During the full follow-up, the CABG group had higher mortality. Cox regression analysis and propensity score matching were used to correct for the effect of other factors influencing mortality. Both analyses showed CABG did not affect survival. In the CABG group, the index infarction was more likely to be NSTEMI than STEMI (HR: 1.612; CI 1.464-1.774; $\mathrm{p}<0.001$ ).

Conclusion: The history of CABG does not affect the life expectancy of patients treated for an acute myocardial infarction.

Keywords: myocardial infarction, coronary bypass grafting, prognosis, myocardial infarction registry

Jánosi A, Ferenci T, Komócsi A, Andréka P. [Short- and long-term prognostic significance of previous recanalization interventions in patients treated for myocardial infarction]. Orv Hetil. 2021; 162(5): 177-184.

(Beérkezett: 2020. július 11.; elfogadva: 2020. augusztus 16.)

\begin{abstract}
Rövidítések
$\mathrm{CABG}=$ (coronary artery bypass grafting) koszorúér-revascularisatiós mûtét; $\mathrm{CI}=$ (confidence interval) konfidenciaintervallum; $\mathrm{HR}=$ (hazard ratio) hazárdhányados; NSTEMI = (non-ST-elevation myocardial infarction) ST-elevációval nem járó myocardialis infarctus; PCI $=$ (percutaneous coronary intervention) katéteres koszorúér-intervenció; RAAS = (reninangiotensin-aldosterone system) renin-angiotenzin-aldoszteron rendszer; STEMI = ST-elevációval járó myocardialis infarctus; TAJ = társadalombiztosítási azonosító jel
\end{abstract}

A szívinfarktus miatt kezelt betegek prognózisát az életkor, a kórelőzményben szereplő történések, a társbetegségek jelenléte és a kezelés módja befolyásolja. Irodalmi közlések és saját adataink is igazolják, hogy a kórelőzményben szereplő ischaemiás esemény (szívinfarktus, stroke), valamint a diabetes mellitus és a perifériás érbetegség rontja az infarktusos betegek életkilátásait [1], míg a magas vérnyomás prognosztikai jelentőségére vonatkozóan nem egyértelmúek az irodalmi adatok [2-4]. Nagyszámú, randomizált vizsgálattal igazolták a katéteres intervenció kedvező hatását az ST-elevációval járó infarktus (STEMI) és a magas rizikójú, ST-elevációval nem járó infarktus (NSTEMI) esetén [5, 6]. Viszonylag kevés adatot ismerünk azzal kapcsolatban, hogy a koszorúér-revascularisatiós mútét $(\mathrm{CABG})$ után elszenvedett infarktus esetén hogyan alakul a betegek prognózisa. A megjelent publikációk kis esetszámúak, és az adatok ellentmondásosak. A Nemzeti Szívinfarktus Regiszter múködése lehetôvé tette, hogy a kérdést válogatás nélküli, nagy betegszám feldolgozásával vizsgáljuk.

\section{Módszer}

A Nemzeti Szívinfarktus Rendszer folyamatosan, online múködő betegségregiszter: ebben minden olyan, szívinfarktus miatt kezelt beteg személyes és klinikai adata rög- zítésre kerül, akinél szívinfarktus miatt kórházi kezelés történt. A jelen vizsgálatban a 2014. január l. és 2017. december 31. között kezelt azon betegek adatait dolgoztuk fel, akik társadalombiztosítási azonosító számmal (TAJ) rendelkeztek. A kórelőzményben szereplő CABG alapján (igen vs. nem) a betegeket két csoportba soroltuk (CABG- vs. kontroll csoport), és vizsgáltuk a betegek kórelőzményi adatait, társbetegségeit, a kezelés módját, valamint a betegek kórlefolyását. A percutan intervenció alkalmával a beavatkozást végző orvos meghatározta az infarktust okozó eret, amelyen a szükséges beavatkozást is elvégezte. Kétséges esetben az adatlapon több ér megjelölése is lehetséges volt. Az indexinfarktust követően 1 évig vizsgáltuk az újabb infarktus, stroke, percutan intervenció, CABG gyakoriságát, valamint a teljes utánkövetési idő alatt követtük a bármely okból bekövetkező halálozást, felhasználva a Nemzeti Egészségügyi Adatkezelő nyilvántartását. A túlélési adatok többváltozós modellezéséhez a Cox-féle proporcionálishazárd-modellt használtuk elsődleges vizsgálati eszközként; ennek eredményeit hazárdhányadosként (HR) adtuk meg. A modell proporcionalitását vizsgáltuk. Alternatív elemzésként 'propensity score matching'-et (becsült részvételi valószínúségen alapuló párosítást) végeztünk „legközelebbi szomszéd” illesztési módszerrel, logisztikus regressziót használva a 'propensity score' elóállítására [7]. Ennek eredményességét a két csoport közötti nyers, illetve standardizált különbség illesztés előtti és utáni értékeinek összehasonlításával végeztük. A számításokat az R statisztikai programcsomag 4.0.0-ás verziójában hajtottuk végre [8].

\section{Eredmények}

\section{A betegek száma és klinikai adatai}

A vizsgált négy év alatt 55599 infarktusbeteg adatait rögzítették az adatbázisban. A kórházi kezelésre 23437 
betegnél (42,2\%) STEMI, míg 32162 esetben (57,8\%) NSTEMI miatt került sor. A STEMI-betegcsoportban a betegek $62 \%$-a, az NSTEMI-betegek között 59\% volt férfi. A teljes betegpopuláció klinikai adatait az 1 . táblázatban foglaltuk össze. Az indexinfarktust megelőzően CABG-mütét az egész betegcsoport 5,33\%-ának (2965 beteg) kórelőzményében szerepelt. Az infarktust megelőző revascularisatiós mütét a STEMI-betegek 2,6\%ában $(\mathrm{n}=608)$, az NSTEMI-betegek 7,3\%-ában $(\mathrm{n}=$ $2357)$ történt. A CABG-csoportban a betegek idősebbek voltak, a kórelőzményükben szereplő ischaemiás

1. táblázat |A vizsgált betegcsoportok klinikai jellemzői

\begin{tabular}{|c|c|c|c|c|}
\hline & $\begin{array}{l}\text { Összes beteg } \\
(\mathrm{n}=55599)\end{array}$ & $\begin{array}{c}\text { Kontroll } \\
(\mathrm{n}=52634)\end{array}$ & $\begin{array}{c}\text { CABG } \\
(n=2965)\end{array}$ & $\mathrm{p}$ \\
\hline Életkor (év) & $67,21 \pm 12,76$ & $67,00 \pm 12,88$ & $70,89 \pm 9,64$ & $<0,001$ \\
\hline $\begin{array}{l}\text { A nők } \\
\text { aránya (\%) }\end{array}$ & $40 \%(22245)$ & $41 \%(21364)$ & $30 \%(881)$ & $<0,001$ \\
\hline \multicolumn{5}{|c|}{ Kórelőzményi adatok } \\
\hline $\begin{array}{l}\text { Myocardialis } \\
\text { infarctus }\end{array}$ & $24 \%(13443)$ & $21 \%(11272)$ & $73 \%(2171)$ & $<0,001$ \\
\hline Stroke & $10 \%(5382)$ & $9 \%(4991)$ & $13 \%(391)$ & $<0,001$ \\
\hline $\begin{array}{l}\text { Szívelég- } \\
\text { telenség }\end{array}$ & $15 \%(8614)$ & $14 \%(7364)$ & $42 \%(1250)$ & $<0,001$ \\
\hline PCI & $22 \%(12052)$ & $19 \%(10087)$ & $66 \%(1965)$ & $<0,001$ \\
\hline \multicolumn{5}{|l|}{ Társbetegségek } \\
\hline Hypertonia & $80 \%(44442)$ & $79 \%(41659)$ & $94 \%(2783)$ & $<0,001$ \\
\hline $\begin{array}{l}\text { Diabetes } \\
\text { mellitus }\end{array}$ & $33 \%(18610)$ & $33 \%(17147)$ & $49 \%(1463)$ & $<0,001$ \\
\hline $\begin{array}{l}\text { Perifériás } \\
\text { érbetegség }\end{array}$ & $14 \%(8016)$ & $14 \%(7154)$ & $29 \%(862)$ & $<0,001$ \\
\hline
\end{tabular}

CABG = koszorúér-revascularisatiós mütét; PCI = katéteres koszorúérintervenció

2. táblázat |STEMI-indexinfarktus esetén a CABG- és a kontrollbetegcsoport klinikai adatainak összehasonlítása

\begin{tabular}{lccc}
\hline & $\begin{array}{c}\text { Kontroll } \\
(\mathrm{n}=22829)\end{array}$ & $\begin{array}{c}\text { CABG } \\
(\mathrm{n}=608)\end{array}$ & $\mathrm{p}$ \\
\hline Életkor (év) & $55,4 \pm 13,1$ & $61,5 \pm 10,7$ & $<0,001$ \\
A nők aránya (\%) & $38 \%(8757)$ & $28 \%(169)$ & $<0,001$ \\
\hline Kórelőzményi adatok & & & \\
\hline Myocardialis infarctus & $14 \%(3299)$ & $68 \%(412)$ & $<0,001$ \\
Stroke & $7 \%(1636)$ & $12 \%(74)$ & $<0,001$ \\
Szívelégtelenség & $9 \%(1947)$ & $37 \%(223)$ & $<0,001$ \\
PCI & $13 \%(2922)$ & $64 \%(387)$ & $<0,001$ \\
\hline Társbetegségek & & & \\
\hline Hypertonia & $73 \%(16619)$ & $90 \%(550)$ & $<0,001$ \\
Diabetes mellitus & $27 \%(6187)$ & $44 \%(268)$ & $<0,001$ \\
Perifériás érbetegség & $9 \%(2157)$ & $27 \%(162)$ & $<0,001$ \\
\hline
\end{tabular}

CABG = koszorúér-revascularisatiós mútét; PCI = katéteres koszorúérintervenció; STEMI = ST-elevációval járó myocardialis infarctus történések és a társbetegségek gyakoribbak voltak. A betegek több mint 90\%-ánál hypertonia, minden második betegnél diabetes mellitus és közel egyharmaduknál perifériás érbetegség volt igazolható. Kiemelendő, hogy a betegek közel háromnegyedénél a CABG-re szívinfarktus után került sor, és e betegek döntő többsége (70\%) férfi volt. A 2. táblázatban a STEMI-, a 3. táblázatban az NSTEMI-betegek adatait közöljük, amelyekben a fentebb leírt arányok figyelhetók meg a CABG- vs. a kontrollbetegcsoportban.

\section{Az utánkövetési idō hossza}

Az utánkövetési idő mediánja 884 nap, azaz közel 2,5 év volt.

\section{Az invazí kezelés gyakorisága, az infarktusért felelós ér vizsgálata}

A teljes betegcsoport 71\%-ánál történt az indexinfarktus kapcsán katéteres koszorúér-intervenció (PCI), a STEMI miatt kezelt betegeknél gyakrabban, mint az NSTEMI-betegcsoportban (84\% vs. 61\%). A STEMIcsoportban az akut esemény során elvégzett PCI a CABG-betegek 71\%-ánál, míg a kontrollcsoportban a $84 \%$-uknál történt $(\mathrm{p}<0,001)$. NSTEMI-diagnózis esetén a PCI aránya a CABG- és a kontrollcsoportban 60\%, illetve $61 \%$ volt $(p=0,247)$. A CABG-betegek esetén minden negyedik infarktust $(26,8 \%)$ graftocclusio, minden kilencedik $(11,5 \%)$ történést fötörzselzáródás okozta. A kontrollbetegek esetén a leggyakrabban (45\%) a bal leszálló koszorúér elzáródása okozott infarktust, míg a második leggyakrabban elzáródott ér a jobb koszorúér volt $(35,1 \%)$.

3. táblázat $\mid$ NSTEMI-indexinfarktus esetén a CABG- és a kontrollbetegcsoport klinikai adatainak összehasonlítása

\begin{tabular}{lccc}
\hline & $\begin{array}{c}\text { Kontroll } \\
(\mathrm{n}=29805)\end{array}$ & $\begin{array}{c}\text { CABG } \\
(\mathrm{n}=2357)\end{array}$ & $\mathrm{p}$ \\
\hline Életkor (év) & $60,7 \pm 12,37$ & $64,8 \pm 9,26$ & $<0,001$ \\
A nők aránya (\%) & $42 \%(12607)$ & $30 \%(712)$ & $<0,001$ \\
\hline Kórelőzményi adatok & & & \\
\hline Myocardialis infarctus & $27 \%(7973)$ & $75 \%(1759)$ & $<0,001$ \\
Stroke & $11 \%(3355)$ & $13 \%(317)$ & $<0,001$ \\
Szívelégtelenség & $18 \%(5417)$ & $44 \%(1027)$ & $<0,001$ \\
PCI & $24 \%(7165)$ & $67 \%(1578)$ & $<0,001$ \\
\hline Társbetegségek & & & \\
\hline Hypertonia & $84 \%(25040)$ & $95 \%(2233)$ & $<0,001$ \\
Diabetes mellitus & $37 \%(10960)$ & $51 \%(1195)$ & $<0,001$ \\
Perifériás érbetegség & $17 \%(4997)$ & $30 \%(700)$ & $<0,001$ \\
\hline
\end{tabular}

CABG = koszorúér-revascularisatiós mútét; $\mathrm{PCI}=$ katéteres koszorúérintervenció; NSTEMI = ST-elevációval nem járó myocardialis infarctus 
A kórházi elbocsátáskor javasolt gyógyszeres kezelés STEMI- és NSTEMI-indexinfarktus esetén a CABG- és a kontrollcsoportban

\begin{tabular}{lcc|cc}
\hline & \multicolumn{2}{c|}{ STEMI } & \multicolumn{2}{c}{ NSTEMI } \\
\hline & CABG & Kontroll & CABG & Kontroll \\
\hline Béta-blokkoló & 85,9 & 86,6 & 90,8 & 88,03 \\
Sztatin & 90,29 & 90,79 & 92,09 & 89,09 \\
RAAS-gátló & 88,38 & 85,8 & 88,42 & 86,28 \\
Aszpirin & 92,38 & 92,52 & 89,83 & 90,06 \\
DAPT & 76,95 & 83,67 & 72,18 & 75,15 \\
DAPT + AC & 9,52 & 5,09 & 9,79 & 5,27 \\
OAK & 11,81 & 6,1 & 15,54 & 8,58 \\
\hline
\end{tabular}

AC = antikoaguláns kezelés; CABG = koszorúér-revascularisatiós mútét; DAPT = kettős vérlemezke-ellenes terápia; NSTEMI = ST-elevációval nem járó myocardialis infarctus; OAK = orális antikoaguláns; RAAS = renin-angiotenzin-aldoszteron rendszer; STEMI = ST-elevációval járó myocardialis infarctus

\section{A kórbázi elbocsátás során javasolt gyógyszeres kezelés megoszlása a vizsgált csoportokban}

A kórházi elbocsátáskor javasolt gyógyszeres kezelés gyakoriságát a 4. táblázatban foglaltuk össze. A béta-blokkoló-, sztatin-, RAAS-gátló, illetve aszpirinkezelés gyakorisága nem különbözött a csoportok között. A kettős thrombocytaaggregáció-gátló kezelést a leggyakrabban azon, STEMI miatt kezelt betegek kapták, akiknél a kórelőzményben nem szerepelt revascularisatiós mütét. Ez magyarázható azzal az adattal, hogy ebben az alcsoportban volt a leggyakoribb az akut esemény kapcsán elvégzett PCI is. Az orális antikoaguláns kezelés (önállóan vagy a hármas kezelés részeként) mindkét típusú infarktus esetén a CABG-csoportban volt lényegesen gyakoribb.

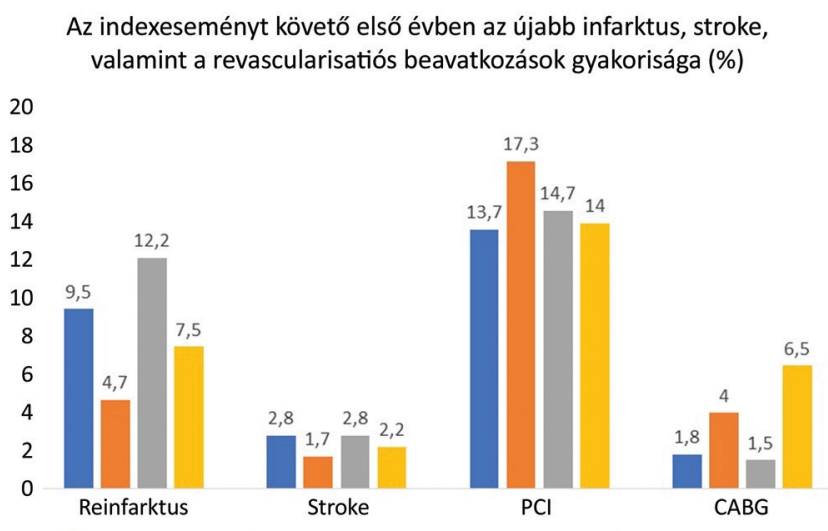

1. ábra

\section{A nem halálos reinfarktus és stroke, valamint a revascularisatiós beavatkozások (PCI, CABG) gyakorisága az utánkövetés elsó évében}

Az ischaemiás történések (reinfarktus, stroke), valamint a revascularisatiós beavatkozások gyakoriságát a 1 . ábra mutatja. A reinfarktus gyakorisága 4,7\% és 12,2\% között változott. Újabb infarktus a leggyakrabban a CABGNSTEMI-betegcsoportban történt. Stroke a betegek 1,7-2,8\%-ában fordult elő, lényeges különbséget a csoportok között nem találtunk. Az akut kezelést követő 1 évben újabb PCI történt a betegek 13,7-17,3\%-ánál. A kontroll-STEMI-csoportban találtuk a legmagasabb értéket, ami elsősorban a nem 'culprit' (felelőssé tehetö) ereken elvégzett késői, tervezett beavatkozásokkal magyarázható. Az 1 éves utánkövetés során elvégzett revascularisatiós mütét gyakorisága 1,5\% és 6,5\% között változott a vizsgált csoportokban. Szívsebészeti revascularisatio a leggyakrabban $(6,5 \%)$ a kontroll-NSTEMIcsoportban történt.

\section{A beteg túlélésének vizsgálata}

A CABG- és a kontroll vizsgálati csoportba tartozó betegek túlélési görbéit NSTEMI, illetve STEMI esetén a 2. ábrán mutatjuk be. A STEMI miatt kezeltek túlélési valószínúsége jobb, mint az NSTEMI-betegeké. Azon alcsoportok esetén, amelyeknél az indexinfarktusra a CABG után került sor, a túlélési valószínűség lényegesen kisebb. A rosszabb túlélés oka lehet a korábban is kezelt érbetegség, annak súlyossága, kiterjedése, de az is ronthatja a betegek életkilátásait, hogy idősebbek, és gyakoribbak a társbetegségek.

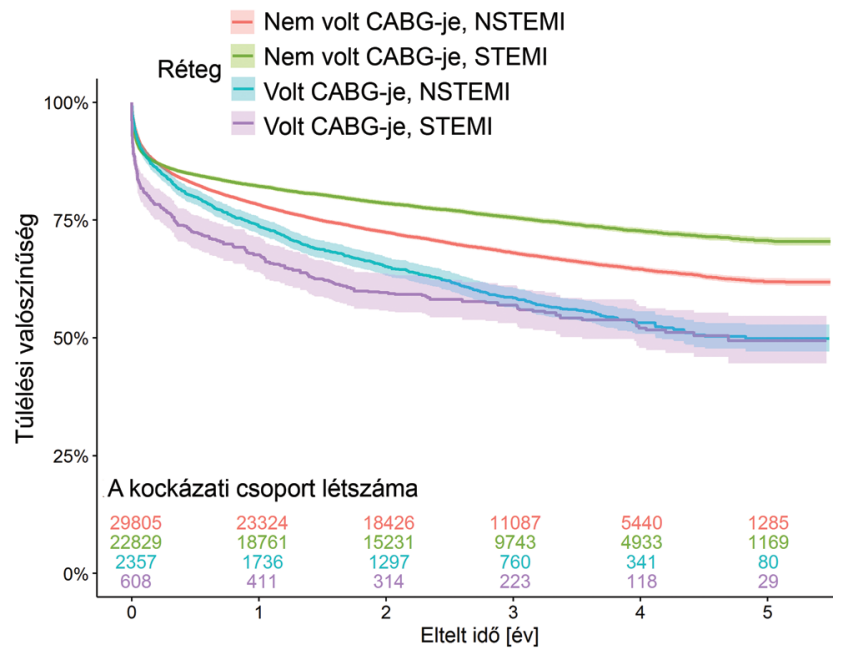

\begin{tabular}{l|l} 
2. ábra & $\begin{array}{l}\text { A vizsgálati csoportok túlélési görbéi az infarktus típusa szerint } \\
\text { CABG = koszorúér-revascularisatiós mútét; NSTEMI }=\text { nem } \\
\text { ST-elevációs myocardialis infarctus; STEMI = ST-elevációval } \\
\text { járó myocardialis infarctus }\end{array}$
\end{tabular} 
A halálozást befolyásoló tényezők hazárdhányadosai a Cox-modellezés alapján

\begin{tabular}{|c|c|c|c|c|}
\hline Változó & HR & \multicolumn{2}{|c|}{$95 \% \mathrm{CI}$} & $\mathrm{p}$ \\
\hline Életkor: +10 év & 1,784 & 1,757 & 1,811 & $<0,001$ \\
\hline Nem: nö : férfi & 0,923 & 0,894 & 0,953 & $<0,001$ \\
\hline $\begin{array}{l}\text { STEMI : NSTEMI } \\
\text { (indexinfarktus) }\end{array}$ & 1,279 & 1,236 & 1,323 & $<0,001$ \\
\hline \multicolumn{5}{|l|}{ Kórelözmény } \\
\hline CABG: igen : nem & 1,021 & 0,961 & 1,085 & 0,501 \\
\hline igen : nem & 0,912 & 0,871 & 0,955 & $<0,001$ \\
\hline Stroke: igen : nem & 1,345 & 1,289 & 1,404 & $<0,001$ \\
\hline $\begin{array}{l}\text { Szívelégtelenség: } \\
\text { igen : nem }\end{array}$ & 1,692 & 1,630 & 1,756 & $<0,001$ \\
\hline \multicolumn{5}{|l|}{ Társbetegségek } \\
\hline $\begin{array}{l}\text { Diabetes mellitus: } \\
\text { igen : nem }\end{array}$ & 1,324 & 1,283 & 1,367 & $<0,001$ \\
\hline Hypertonia: nem : igen & 1,146 & 1,096 & 1,199 & $<0,001$ \\
\hline $\begin{array}{l}\text { Perifériás érbetegség: } \\
\text { igen : nem }\end{array}$ & 1,444 & 1,390 & 1,500 & $<0,001$ \\
\hline
\end{tabular}

CABG = koszorúér-revascularisatiós mútét; $\mathrm{CI}=$ konfidenciaintervallum; HR = hazárdhányados; NSTEMI = ST-elevációval nem járó myocardialis infarctus; STEMI = ST-elevációval járó myocardialis infarctus

\section{A túlélés többváltozós modellezése}

A modellezést a Cox-féle proporcionálishazárd-modellel végeztük oly módon, hogy a kórelőzményben szereplő CABG-t interakcióba hoztuk az ugyancsak a kórelőz- ményben szereplő PCI-vel, azaz külön eredményt kaptunk a kórelőzményi CABG hatására azok körében, akiknél volt PCI, és azok körében, akiknél nem volt. Az előzetes vizsgálatok alapján a modellt a kórelőzményben szereplő infarktusra rétegeztük, mivel abban lényeges nem proporcionalitás mutatkozott. Az előbb említett interakció nem volt szignifikáns $(\mathrm{p}=0,797)$, tehát a $\mathrm{CABG}$ hatása ugyanaz volt akkor, ha a betegnél volt PCI, illetve ha nem volt. A Cox-modell eredményeit az 5. táblázatban foglaltuk össze. A korábbi vizsgálatokból jól ismert prognosztikai tényezők (életkor, korábbi szívelégtelenség, diabetes mellitus, perifériás érbetegség stb.) a jelen vizsgálat alapján is növelték az elhalálozás kockázatát, ugyanakkor az indexinfarktust megelózően elvégzett CABG nem befolyásolta a betegek életkilátásait $(\mathrm{HR}=$ 1,021; 95\% CI: 0,961-1,085; $\mathrm{p}=0,501)$.

\section{'Propensity score matching'}

A 'propensity score' alapján történő elemzést 2965 beteg körében végeztük el. A 'matching' eredményességét a 3. ábra szemlélteti, amelyben a függóleges vonal jelzi a két csoport jó illeszkedését. Az illesztés utáni csoportok túlélési görbéjét az illesztett adatokon a 4. ábra mutatja. A többfaktoros elemzés eredményei az 5. ábrán láthatók: az indexinfarktus előtt elvégzett CABG nem befolyásolta a betegek infarktus utáni túlélését: HR: 1,007 (95\% CI: 0,932-1,09; $\mathrm{p}=0,853$ ), ami megegyezik azzal, amit a Cox-modellel történt vizsgálatunkban találtunk.

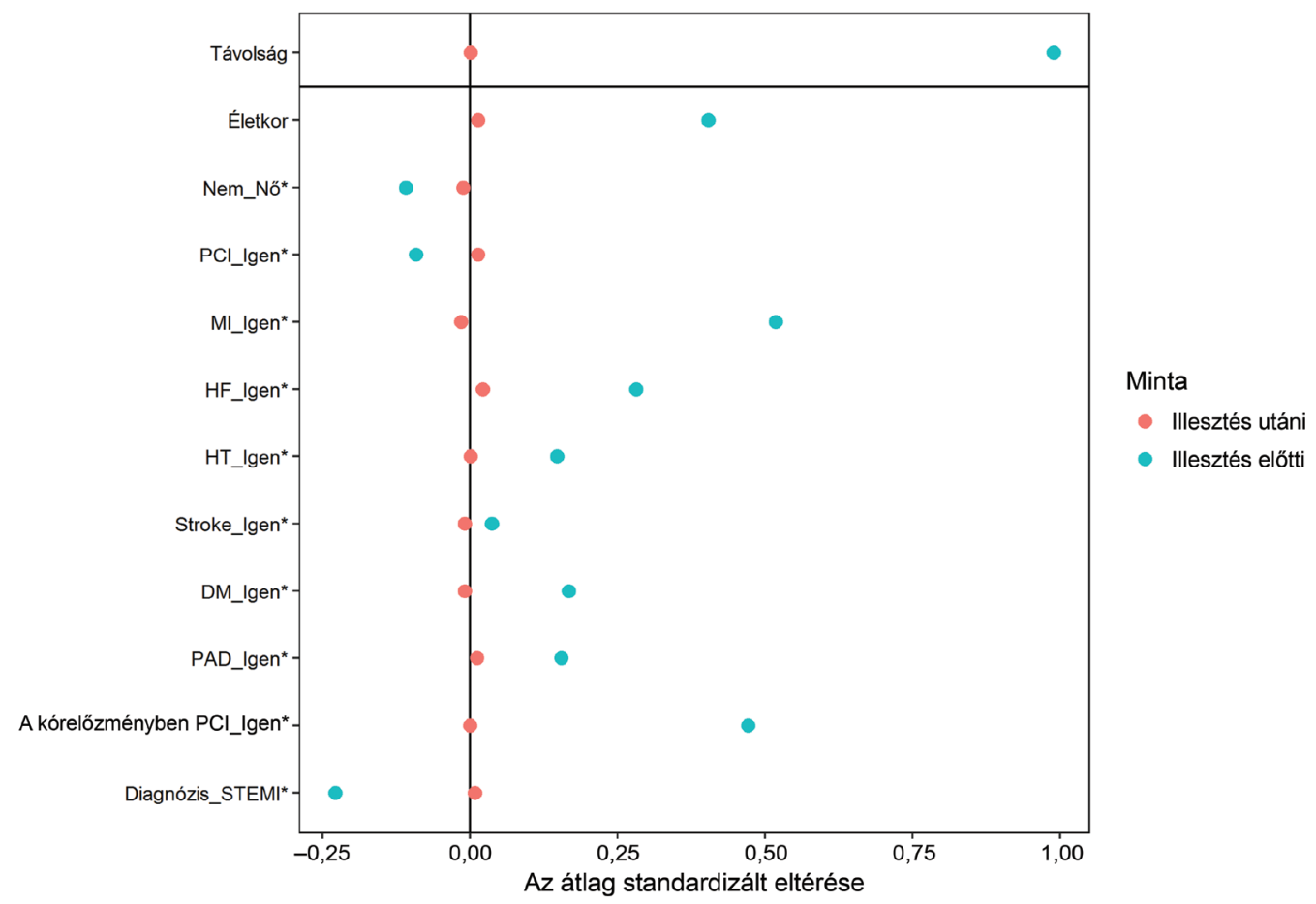

\begin{tabular}{l|l} 
3. ábra & $\begin{array}{l}\text { 'Propensity score matching': a csoportok illeszkedése a matching előtt és után } \\
\mathrm{DM}=\text { diabetes mellitus; HF = szívelégtelenség; HT = szívtranszplantáció; } \mathrm{MI}=\text { myocardialis infarctus; PAD = perifériás veróérbetegség; PCI = katé- } \\
\text { teres koszorúér-intervenció; STEMI = ST-elevációval járó myocardialis infarctus }\end{array}$
\end{tabular} 


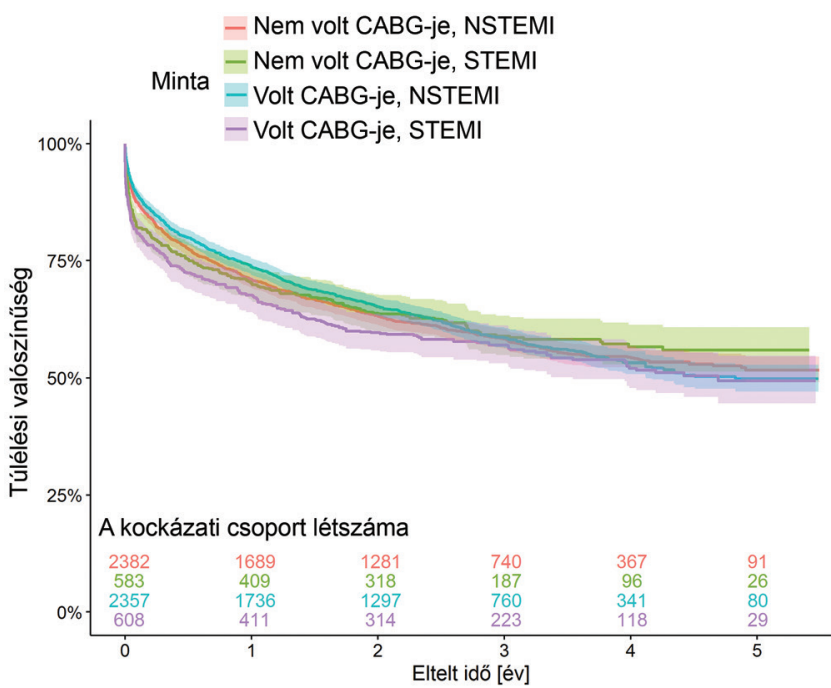

4. ábra

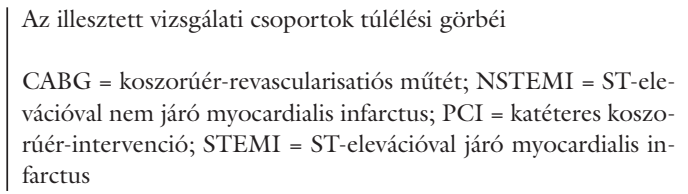

6. táblázat $\mid$ Az indexinfarktus típusának vizsgálata logisztikus regressziós elemzéssel

\begin{tabular}{lc|cr|c}
\hline Változó & HR & \multicolumn{2}{|c|}{$95 \%$ CI } & $p$ \\
\hline CABGI vs. CABGN & 1,612 & 1,464 & 1,774 & $<0,001$ \\
$\begin{array}{l}\text { Diabetes mellitus: } \\
\text { igen : nem }\end{array}$ & 1,231 & 1,184 & 1,280 & $<0,001$ \\
Hypertonia: nem : igen & 0,716 & 0,684 & 0,749 & $<0,001$ \\
Perifériás érbetegség: & 1,351 & 1,278 & 1,427 & $<0,001$ \\
igen : nem & & & & \\
Életkor: 10 : 00 & 1,237 & 1,219 & 1,256 & $<0,001$ \\
Nem: nó : férfi & 1,000 & 0,964 & 1,038 & 0,984 \\
\hline Kórelőzmény & & \multicolumn{3}{|c}{} \\
\hline Myocardialis infarctus & 1,341 & 1,263 & 1,423 & $<0,001$ \\
PCI: igen : nem & 1,433 & 1,348 & 1,523 & $<0,001$ \\
Stroke: igen : nem & 1,167 & 1,095 & 1,243 & $<0,001$ \\
Szívelégtelenség: & 1,506 & 1,424 & 1,593 & $<0,001$ \\
igen : nem & & \multicolumn{3}{|c}{} \\
\hline
\end{tabular}

CABGI = koszorúér-revascularisatiós mútét - igen; CABGN = koszorúér-revascularisatiós mútét - nem; $\mathrm{CI}=$ konfidenciaintervallum; $\mathrm{HR}=$ hazárdhányados; PCI = katéteres koszorúér-intervenció

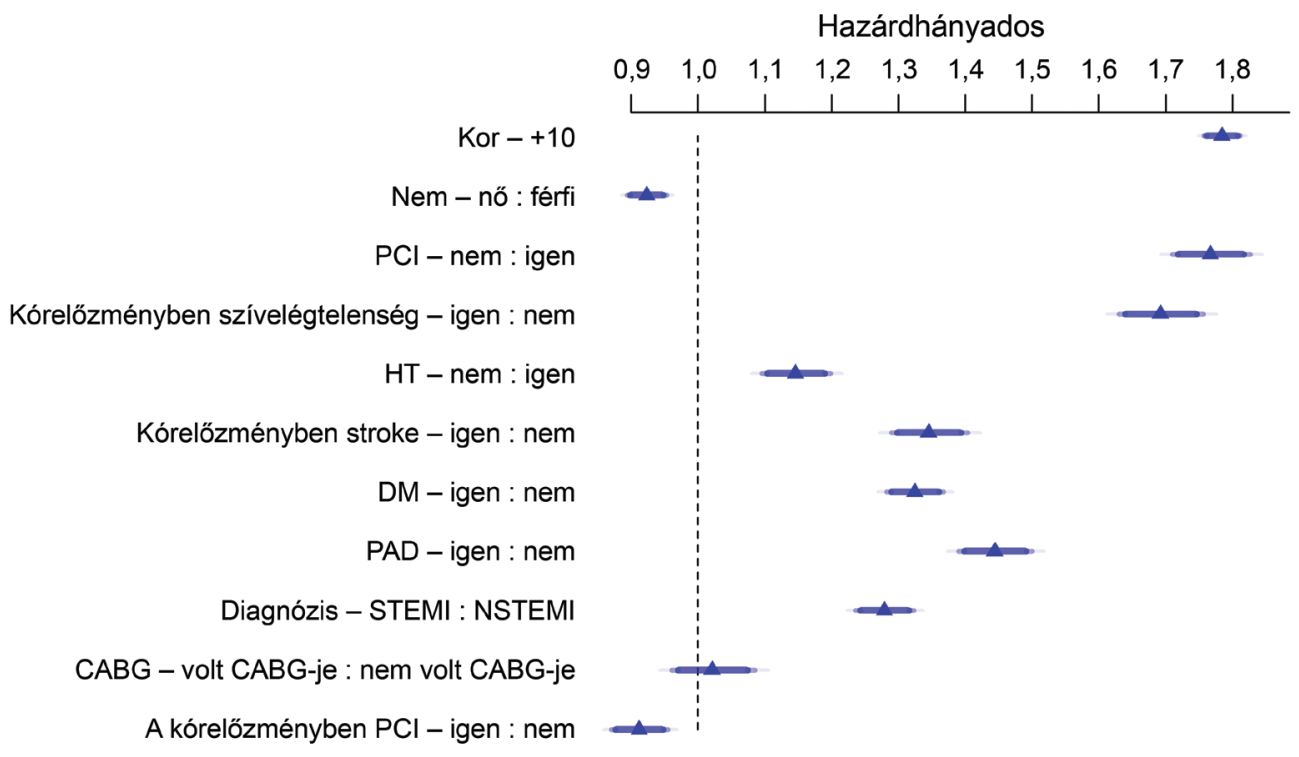

5. ábra

Többfaktoros elemzés a túlélést befolyásoló tényezők vizsgálatár

CABG = koszorúér-revascularisatiós mútét; DM = diabetes mellitus; HT = szívtranszplantáció; NSTEMI = ST-elevációval nem járó myocardialis infarctus; $\mathrm{PAD}$ = perifériás verőérbetegség $; \mathrm{PCI}$ = katéteres koszorúér-intervenció; $\mathrm{STEMI}=\mathrm{ST}$-elevációval járó myocardialis infarctus

\section{A kórelözményben szereplö $C A B G$ és az indexinfarktus típusának vizsgálata}

Az adatok elemzése során felmerült, hogy a kórelőzményben szereplő CABG és az indexinfarktus típusa között összefüggés van. A kérdés tanulmányozásához logisztikus regresszió alkalmazásával vizsgáltuk az egyes változók hatását arra vonatkozóan, hogy a betegnél az indexinfarktus NSTEMI lesz. Az eredményt a 6. táblázatban foglaltuk össze. Amennyiben a betegnél az indexinfarktus elött revascularisatiós mútét történt, akkor
- kontrollálva nemre, életkorra, a kórelőzményi adatokra és a társbetegségekre - az indexinfarktus típusa másfélszer nagyobb eséllyel lesz NSTEMI, mint STEMI (HR = 1,612; 95\% CI: $1,464-1,774 ; \mathrm{p}<0,001)$.

\section{Megbeszélés}

A CABG több mint 50 évvel ezelőtt került először klinikai alkalmazásra, ami René Favaloro nevéhez füződik, bár a koszorúér-szúkület sebészi kezelésével kapcsolatban már korábban is történtek próbálkozások [9]. A ko- 
szorúér-szúkület kezelésének újabb mérföldkövét jelentette a katéteres értágítás és a sztentbeültetés bevezetése és elterjedése. Jelenleg mindkét módszernek fontos szerepe van a betegek gyógyításában, és az optimális beavatkozás - megfelelő kezelési útmutatók alapján - kerül megválasztásra. Fontos szempont, hogy mindkét revascularisatiós beavatkozás - az optimális gyógyszeres kezeléssel kiegészítve - javítja a betegek funkcionális állapotát, esetenként meghosszabbítja az életet, de nem gyógyítja meg az atherosclerosist, s ennek következtében az újabb ischaemiás esemény (például szívinfarktus) kialakulása mindennapos klinikai probléma.

Vizsgálatunkban azon betegek klinikai adatait és prognózisát elemeztük, akiknél CABG után szívinfarktus alakult ki. A Nemzeti Szívinfarktus Regiszter múködése lehetővé tette, hogy nagyszámú, válogatás nélküli beteggel kapcsolatban végezzünk elemzést. Adataink szerint a CABG-betegcsoportba tartozók - mindkét típusú infarktus esetén - idősebbek, kórelőzményükben gyakrabban szerepel ischaemiás történés, és több a társbetegségük, mint azoknak, akiknél az infarktust megelőzően nem végeztek revascularisatiós mútétet. A kontrollcsoportban az infarktusért felelős ér tekintetében a leggyakoribb a bal anterior leszálló koszorúér occlusiója volt, amelyet gyakorisági sorrendben a jobb koszorúér és a körbefutó ér (ramus circumflexus) követett. A CABGbetegek esetén a natív erek occlusiója egyforma gyakorisággal fordult elő, graftocclusio okozta infarktus minden negyedik betegnél volt igazolható. A halálozást vizsgálva - mindkét típusú infarktus esetén - a CABG-betegek rosszabb prognózisát észleltük. A túlélést befolyásoló egyéb tényezők korrigálására Cox-féle regressziós analízist végeztünk: ennek során nem különbözött a CABG-, illetve a kontrollbetegek prognózisa. Hasonló eredményt kaptunk a 'propensity score matching' elemzés során is. A CABG-nek tehát - a befolyásoló tényekre való korrigálás után - sem a korai, sem a késői prognózis vizsgálatakor nem volt prognosztikai jelentősége.

Több szerző [10-13] hasonló adatokról számolt be, míg olyan megfigyelések is idézhetők, amelyek CABG esetén a betegek korai, illetve késői prognózisát roszszabbnak találták [14-16]. Saját adataink, valamint más szerzők munkája arra utal, hogy a CABG kedvezőtlen prognosztikai jelentőségét az magyarázza, hogy ebben a csoportban a betegek idősebbek, és több társbetegségük van - ha ezen tényezőkkel korrigáljuk az összehasonlítást, akkor a korábbi CABG kedvezőtlen prognosztikai hatása már nem mutatható ki $[17,18]$. Detre és mtsai [19] azt vizsgálták, hogy az indexinfarktus alkalmával melyik betegcsoport életkilátása kedvezőbb: akiknél korábban PCI vagy CABG történt? Adataik szerint a CABG után elszenvedett infarktus esetén kedvezőbb életkilátás várható. Többen vizsgálták, hogy a CABG-mútét után kialakuló infarktusért melyik ér felelős (az operált vagy a natív erek valamelyike). Ahogy fentebb már említettük, anyagunkban a natív erek elzáródása lényegesen gyako- ribb volt (csak minden negyedik infarktus esetén találtunk graftocclusiót); ez a megfigyelésünk megegyezik az irodalmi adatok többségével $[11,12]$.

\section{Következtetés}

Heveny szívinfarktus esetén a kórelőzményben szereplő revascularisatiós mútét nem jelent a beteg számára fokozott halálozási kockázatot.

Anyagi támogatás: A közlemény megírása anyagi támogatásban nem részesült.

Szerzői munkamegosztás: J. A.: A vizsgálat tervezése, a kézirat megírása. F. T.: Biostatisztikai elemzés. K. A.: A kézirat összeállításában való részvétel. A. P.: A kézirat végleges formájának kialakításában való részvétel. A cikk végleges változatát valamennyi szerző elolvasta és jóváhagyta.

Érdekeltségek: A szerzőknek a témával kapcsolatban nincsenek érdekeltségeik.

\section{Irodalom}

[1] Canto JG, Kiefe CI, Rogers WJ, et al. Atherosclerotic risk factors and their association with hospital mortality among patients with first myocardial infarction (from the National Registry of Myocardial Infarction). Am J Cardiol. 2012; 110: 1256-1261.

[2] Jánosi A, Ferenci T, Kőszegi Zs, et al. Myocardial infarction without obstructive coronary artery disease (MINOCA) - prevalence and prognosis. [Obstruktív koszorúér-betegség nélkül kialakuló heveny szívizominfarktus (MINOCA) - gyakoriság és prognózis.] Orv Hetil. 2019; 160: 1791-1797. [Hungarian]

[3] El-Meouch NM, Ferenci T, Jánosi A. Effect of smoking on survival after myocardial infarction - smoker's paradox in Hungary? [A dohányzás hatása a szívinfarktus utáni túlélésre - dohányzási paradoxon Magyarországon?] Orv Hetil. 2018; 159: 557-565. [Hungarian]

[4] Gustafsson F, Køber L, Torp-Pedersen C, et al. Long-term prognosis after acute myocardial infarction in patients with a history of arterial hypertension. TRACE study group. Eur Heart J. 1998; 19: 588-594.

[5] Ibanez B, James S, Agewall S, et al. 2017 ESC Guidelines for the management of acute myocardial infarction in patients presenting with ST-segment elevation: The Task Force for the management of acute myocardial infarction in patients presenting with ST-segment elevation of the European Society of Cardiology (ESC). Eur Heart J. 2018; 39: 119-177.

[6] Roffi M, Patrono C, Collet JP, et al. 2015 ESC Guidelines for the management of acute coronary syndromes in patients presenting without persistent ST-segment elevation: Task Force for the management of acute coronary syndromes in patients presenting without persistent ST-segment elevation of the European Society of Cardiology (ESC). Eur Heart J. 2016; 37: 267-315.

[7] Ho D, Imai K., King G, et al. Matching as nonparametric preprocessing for reducing model dependence in parametric causal inference. Polit Anal. 2007; 15: 199-236.

[8] R Core Team. A language and environment for statistical computing. R Foundation for Statistical Computing. Vienna, 2020. Available from: https://www.R-project.org/ [accessed: August $15,2020]$. 
[9] Jánosi A. The first coronary artery revascularization surgery was performed fifty years ago. [Ötven évvel ezelőtt végezték az elsô koszorúér-revascularisatiós mútétet.] Orv Hetil. 2017; 158: 1517-1518. [Hungarian]

[10] Nikolsky E, Mehran R, Yu J, et al. Comparison of outcomes of patients with ST-segment elevation myocardial infarction with versus without previous coronary artery bypass grafting (from the Harmonizing Outcomes With Revascularization and Stents in Acute Myocardial Infarction [HORIZONS-AMI] trial). Am J Cardiol. 2013; 111: 1377-1386.

[11] Iqbal J, Kwok CS, Kontopantelis E, et al. Outcomes following primary percutaneous coronary intervention in patients with previous coronary artery bypass surgery. Circ Cardiovasc Interv. 2016; 9: e003151.

[12] Neuman Y, Pereg D, Boyko V, et al. Primary angioplasty in patients following coronary artery bypass surgery: trends in application and outcome. Results from the acute coronary syndrome Israeli Survey (ACSIS) 2000-2008. Catheter Cardiovasc Interv. 2011; 78: 532-536

[13] Garg P, Kamaruddin H, Iqbal J, et al. Outcomes of primary percutaneous coronary intervention for patients with previous coronary artery bypass grafting presenting with ST-segment elevation myocardial infarction. Open Cardiovasc Med J. 2015; 9: 99104.

[14] Kohl LP, Garberich RF, Yang H, et al. Outcomes of primary percutaneous coronary intervention in ST-segment elevation myocardial infarction patients with previous coronary bypass surgery. JACC Cardiovasc Interv. 2014; 7: 981-987.
[15] Murphy A, Hamilton G, Andrianopoulos N, et al. One-year out comes of patients with established coronary artery disease presenting with acute coronary syndromes. Am J Cardiol. 2019; 123: 1387-1392.

[16] Welsh RC, Granger CB, Westerhout CM, et al. Prior coronary artery bypass graft patients with ST-segment elevation myocardial infarction treated with primary percutaneous coronary intervention. JACC Cardiovasc Interv. 2010; 3: 343-351.

[17] Stone GW, Brodie BR, Griffin JJ, et al. Clinical and angiographic outcomes in patients with previous coronary artery bypass graft surgery treated with primary balloon angioplasty for acute myocardial infarction. Second Primary Angioplasty in Myocardial Infarction Trial (PAMI-2) Investigators. J Am Coll Cardiol. 2000; 35: 605-611.

[18] Gruberg L, Hellkamp AS, Thomas LE, et al. The association of previous revascularization with in-hospital outcomes in acute myocardial infarction patients: results from the National Cardiovascular Data Registry. JACC Cardiovasc Interv. 2015; 8: 19541962.

[19] Detre KM, Lombardero MS, Brooks MM, et al. The effect of previous coronary-artery bypass surgery on the prognosis of patients with diabetes who have acute myocardial infarction. Bypass Angioplasty Revascularization Investigation Investigators. N Engl J Med. 2000; 342: 989-997.

(Jánosi András dr., Budapest, Haller u 29., 1096 e-mail: andras.janosi@kardio.hu) 